\title{
INSECT SCIENCE
} AND ITS APPLICATION

The International Journal of Tropical Insect Science

Founded by

Thomas R. Odhiambo

Editor-in-Chief

K. N. Saxena

The International Centre of Insect Physiology and Ecology (ICIPE) 


\section{Insect Science and its Application The International Journal of Tropical Insect Science}

Sponsored by the International Centre of Insect Physiology and Ecology (ICIPE) and the African Association of Insect Scientists (AAIS)

Founded by: Thomas R. Odhiambo

Editor-in-Chief: K. N. Saxena

Associate Editors: R. W. Mwangi, J. A. Odera and R. K. Saini

Senior Scientific Editor: Serah W. Mwanycky

The International Centre of Insect Physiology and Ecology (ICIPE), P.O. Box 30772, Nairobi, Kenya

\section{Editorial Advisory Board}

F. T. Abushama, Khartoum, Sudan

H. C. Agarwal, Delhi, India

C. Campanhola, Capinas, Sao Paulo, Brazil

I. Fagoonee, Reduit, Mauritius

R. Galun, Jerusalem, Israel

A. Hayes, Auckland, New Zealand

H. Hirumi, Nairobi, Kenya

A. G. Ibrahim, Serdang, Selangor, Malaysia

R. Kumar, Port Moresby, Papua New Guinea
A. Mansingh, Mona, Kingston, Jamaica

A. I. Mohyuddin, Rawalpindi, Pakistan

H. Rembold, Munich, West Germany

P. N. Srivastava, Montreal (Quebec), Canada

G. L. Teetes, College Station, Texas, USA

H. F. van Emdén, Reading, United Kingdom

A. van Huis, Wageningen, The Netherlands

J. H. Visser, Wageningen, The Netherlands

\section{PUBLISHED BIMONTHLY}

Annual Subscription

For libraries, university departments, government laboratories, industrial and other multiple reader institutions US\$210.00 (1993); 2-year rate (1993-1994) US\$ 410.00 (including postage and insurance), private individuals US\$100.00 (1993); 2-year rate US\$160.00 (1993-1994). Specially Reduced Rates for Individuals: In the interest of maximizing the dissemination of the research results published in this important international journal we have established a two-tier price structure. Any individual whose institution takes out a library subscription may purchase a second or additional subscription for personal use at a much reduced rate of US\$ 98.00 (1993); 2-year rate (1993-1994) US\$ 158.00. Members of the International Centre of Insect Physiology and Ecology (ICIPE) and the African Association of Insect Scientists (AAIS) may purchase a subscription at the special rate of US $\$ 20.00$ (1993); 2-year rate (1993-1994) US\$40.00.

Application forms for membership of the AAIS (registration fee US\$20.00; annual membership fee US\$20.00) may be obtained from: Hon. Secretary, African Association of Insect Scientists, P.O. Box 59862, Nairobi, Kenya.

Prices are subject to amendment without notice

Copyright (C) 1993-The International Centre of Insect Physiology and Ecology

It is a condition of publication that manuscripts submitted to this journal have not been published and will not be simultaneously submitted or published elsewhere. By submitting a manuscript, the authors agree that the copyright for their article is transferred to the publisher if and when the article is accepted for publication. However, assignment of copyright is not required from authors who work for organizations which do not permit such assignment. The copyright covers the exclusive rights to reproduce and distribute the article, including reprints, photographic reproductions, microform or any other reproductions of similar nature and translations. No part of this publication may be reproduced, stored in a retrieval system or transmitted in any form or by any means, electronic, electrostatic, magnetic tape, mechanical photocopying, recording or otherwise, without permission in writing from the copyright holder.

\footnotetext{
Photocopying information for users in the USA
}

The Item-fee Code for this publication indicates that authorization to photocopy items for internal or personal use is granted by the copyright holder for libraries and other users registered with the Copyright Clearance Center (CCC) Transactional Reporting Service, provided the stated fee for copying beyond that permitted by Section 107 or 108 of the US Copyright Law, is paid. The appropriate remittance of $\$ 3.00$ per copy per article is paid directly to the Copyright Clearance Center Inc., 27 Congress Street. Salem, MA 01970 .

\section{Permission for other use}

The copyright owner's consent does not extend to copying for general distribution, for promotion, for creating new works or for resale. Specific written permission must be obtained from the publisher of such copying.

\section{ICIPE SCIENCE PRESS P. O. Box 72913, Nairobi, Kenya}

